\title{
'Read, Listen, Discuss, Act': Adult Education, Rural Citizenship and the Canadian National Farm Radio Forum 1941-1965
}

\author{
R.W. Sandwell \\ OISE/University of Toronto
}

\begin{abstract}
The Canadian National Farm Radio Forum was launched in January 1941 as an innovative partnership among three newly-formed organizations: the Canadian Association for Adult Education (CAAE), the Canadian Broadcasting Corporation (CBC), and the Canadian Federation of Agriculture (CFA). During the winter months from 1941 to 1965, the Farm Radio Forum supplemented weekly radio broadcasts for the casual listener with printed educational materials that were mailed in advance to registered rural discussion forums. This article explores these broadcasts, and argues that the discussions and the reports send back from the discussion groups to the central offices of the National Farm Radio Forum provided the core of a distinctive and immensely popular experiment in adult education and grassroots rural, often radical, social activism in mid-twentieth century Canada.
\end{abstract}

\section{RÉSUMÉ}

Lancée en janvier 1941, la Tribune radiophonique agricole nationale du Canada s'est avéré un partenariat innovateur de trois organismes fondés depuis peu : l'Association canadienne pour l'éducation des adultes (ACÉA), la Société Radio-Canada (SRC) et la Fédération canadienne de l'agriculture (FCA). Pendant les mois d'hiver de 1941 à 1965, la Tribune radiophonique agricole en complément de ses émissions hebdomadaires fournissait à l'intention de ses auditeurs du matériel pédagogique expédié à l'avance, par la poste, à des forums de discussion agréés. Cet article étudie ces émissions et soutient que les discussions ainsi suscitées et les rapports subséquents envoyés par les groupes de discussion au siège social de la Tribune radiophonique agricole constituaient le cour d'une expérience particulière très appréciée en éducation des adultes et en activisme populaire — souvent radical — au milieu du vingtième siècle au Canada.

\section{Introduction}

The Canadian National Farm Radio Forum was launched in January 1941 as an innovative partnership among three newly-formed organizations: the Canadian Association for Adult Education (CAAE) the Canadian Broadcasting Corporation 
(CBC) and the Canadian Federation of Agriculture (CFA). During the winter months from 1941 to 1965 , the Farm Radio Forum supplemented weekly radio broadcasts for the casual listener with printed educational materials that were mailed in advance to registered rural discussion forums. These broadcasts, the discussions, and the reports send back from the discussion groups to the central offices of the National Farm Radio Forum provided the core of a distinctive and immensely popular experiment in adult education and grassroots rural, often radical, social activism in mid-twentieth century Canada. With its motto "Read, Listen, Discuss, Act," the National Farm Radio Forum went well beyond the delivery of educational broadcasts to farmers, providing instead what co-founder and rural educator and activist Alex Sim called an "altogether new approach to education and to democratic citizenship:"

[Broadcast] topics ranged from agricultural policy and international trade to community and family life. Families would gather in each others' homes, community halls, school houses or church basements to listen to the broadcast and discuss the issues presented. They were aided with a publication called the Farm Forum Guide which they received prior to the broadcast. The guide presented different sets of questions for both adults and youth to discuss. Following the discussion, the participants were encouraged to report to their Provincial Farm Forum Office the results of their discussion and these were tabulated and reported for five minutes of the following week's broadcast. This allowed the listeners to take part in their education by sharing views and ideas across the country. ${ }^{2}$

The Farm Radio Forum format responded to a widely recognized need to provide the educational support that farm families (including both men and women) needed to analyze and develop their own solutions to a variety of acute problems confronting them in the wake of the economic and environmental disasters of the Great Depression. Its purpose was to provide the communication infrastructure needed for rural education and social activism by exploiting the democratic potential of the new media - the radio. The Farm Radio Forum was remarkably successful. Recognized as the "longest and most apparently successful listening groups projects in the world" and dubbed "one of the greatest adult educational movements of the time," ${ }^{\prime 4}$ at its peak in 1949, it consisted of over 1,600 registered Forums, with over 21,000 registered individuals listening to a single broadcast nationwide. ${ }^{5}$ As early as 1942 , it was reported that a single broadcast had been given a hearing by "an audience larger than all the farm meetings in the country put together." ${ }^{\prime 6}$

In 1952, the Farm Radio Forum's success attracted the interest of UNESCO, which commissioned a research report about the Forum. A highly favourable, detailed report, written by John Nicol, Albert A. Shea, G.J.P. Simmins, and edited by R.Alex Sim was published in 1954 entitled Canada's Farm Radio Forum. The report provides detailed information, much of it based on surveys and questionnaires that supplemented the information gathered by the Farm Forum itself, on its mandate, organizational structure, and membership. It includes a detailed Communications 
Study that documents the variety and success of the Forum's multi-media approach, and a very detailed report on the origins and activities of the Farm Radio Forum in one particularly successful area, Halton County, Ontario. As a result of that report, Canada's Farm Radio Forum soon after became a model for Radio Forums throughout the developing world, first in India, Ghana and France, and later in Africa. While the Farm Radio Forum ended in Canada in 1965, a number of those originally involved went on to found in 1979 Farm Radio Forum International which, by 2008, was involved in developing community-based, farmer-centred broadcasting in Poona, India; Philippines, Tanzania, Malawi, Mali, Mozambique, Ghana, and South Africa. The Farm Radio Forum format pioneered in Canada in the mid-twentieth century was, by the early twenty-first, being broadcast on more than 700 radio stations in 110 countries worldwide, with an audience of over 150 million farmers a month, and as many as 39 million people listening to a single broadcast. ${ }^{7}$

This article provides a preliminary exploration of the rural origins, scope, and educational objectives of this original — and remarkable - Canadian experiment. While this paper stops well short of evaluating the success of the Farm Radio Program as a form of adult education, rural citizenship or social activism, I hope to draw educational and rural historians' attention to this all-too-rare window on a "major social institution of the period" 8 that championed rural citizenship, identity, and adult education in some surprising ways in the middle years of the twentieth century.

\section{The Economic, Political and Social Contexts of Rural Canada}

Although historians have tended to focus on urbanization as the key aspect of the transformations Canadians experienced in the first half of the $20^{\text {th }}$ century, this paper is part of a growing body of work suggesting that rural and (very) small town populations comprised a significant portion of Canadian society and economy until the 1950s. For, notwithstanding a rapid increase in the proportion of Canadians living in cities and towns, particularly in the 1890-1921 period, it was only in 1941 that for the first time a majority of Canadians lived in urban communities larger than 1,000; it was only in 1961 that a majority of Canadians lived in communities larger than 5,000. Notwithstanding the slow increase in the proportion of Canadians living in urban areas in the 1921-1951 period, it was not until 1976 that Canada's rural population fell for the first time ever. ${ }^{9}$ As Adam Crerar has argued, even in Ontario, one of the most rapidly urbanizing provinces, up until the 1930s "the existence of prosperous farming districts and large urban populations with roots in the countryside ensured that farming and conceptions of farming played a central role in the provinces' society and culture even as towns and cities expanded." 10

Arguably, therefore, Canada remained a rural country, and Canadians were overwhelmingly a rural people, well into the twentieth century. And rural society differed in some significant ways from the rapidly growing urban population. Evidence from across Canada provided by a number of historians is emphasizing not only the persistence of rural populations, but the fact that social and socialist reform in Canada was, up until the 1950s, an important rural phenomenon. ${ }^{11}$ With overproduction driving 
down prices in global markets and threatening farm incomes, with 'big business' taking what farmers considered an unreasonable portion of their profits, and with urban industrialization providing what many rural people understood as an unworkable model of the future of Canadian communities, a significant rural reform movement grew up throughout the first half of the twentieth century. ${ }^{12}$ As Christie and Gauvreau document, many reformers believed Canada's future would be rural, predominantly agricultural and probably based on the co-operative values and practices of collective action for the people, rather than towards the support of urban big business and isolated individualism. ${ }^{13}$ And many among the millions of Canadians living in rural Canada before 1950 were simply unable to contemplate a society where the government would continue to develop and support policies favouring urban manufacturing interests at the expense of rural and agricultural ones. Those who could not imagine a permanent decline in rural populations or the increasing growth of urban Canadian society continued to look for and fight for solutions to 'the rural problem' well into the middle decades of the twentieth century. While much more research is needed to understand the anti-urban sentiments and rural futures imagined in these years, it is clear that beliefs varied significantly about just what that future would hold for rural Canadians. But evidence suggest that many believed that if only rural people could be freed from the poverty and isolation that derived from the policies that disproportionately favoured urban and industrial interests, their future would be worked out within the contours of what James Murton has phrased the " modern rural." 14

By the mid-1930s, many rural dwellers across the country had largely given up what limited faith they might have possessed in provincial efforts to improve farming and farm life by providing university-educated experts to teach farmers scientific methods through farm instruction. ${ }^{15}$ The Great Depression had made it clear that these initiatives were largely beside the point. The Canadian Federation of Agriculture (CFA) was created in the mid-1930s to deal with the growing recognition that "the pressing problems of farming now are those connected with marketing, distribution, farm incomes and social organization." ${ }^{16}$ Even by 1940, after the Second World War had begun to bring economic prosperity to urban populations, conditions for farmers remained disproportionately dire. As CFA representative Donald Cameron noted in his annual address to the Canadian Association of Adult Education at in 1940, "the rural dwellers of Canada comprise one third of the population and provide one half of the National wealth and receive one twelfth of the National income." ${ }^{17}$ Neil M. Morrison, who shared in the CBC production of the first Farm Forum programs, explained farmers' difficulties in his 1939 proposal for the Farm Radio Forum project:

I was first struck by the growing seriousness of the rural situation last spring while I was working on the Community Clinic broadcasts in Quebec ... talking to farmers and their wives about our broadcasts and their problems. I was struck with the vehemence of feeling displayed by some of them. And nearly all of them had the same complaint in varying degrees - low price of commodities they were selling and high price of feed .... This dissatisfaction among farmers is directed partly at the government for its 'do nothing' policy 
and partly at the large packers and manufacturers and financial houses. They feel they are being exploited by the latter groups and that the government is doing nothing to prevent it or else is actually helping 'big business' by giving it protection in one form or another. ${ }^{18}$

As Morrison concluded, "the indefiniteness on the part of the authorities about this and other matters of government policy as well as the general lack of concrete facts and information, has had a very bad effect on public confidence and morale."19

In the late 1930s, a number of individuals interested in solving the problems of twentieth century farm families came together from three different organizations to create the National Farm Radio Forum as a remedy to farm problems: R.A. Sim (rural activist, broadcaster and a rural educator at McGill University's Macdonald College) and E.A. Corbett (formerly a university professor at the University of Alberta) from the Canadian Association for Adult Education; H.H. Hannum (previously the secretary of the United Farmers of Ontario) from the Canadian Federation of Agriculture, and Gladstone Murray (previously involved in 'listening groups' with the BBC in England) and N. M. Morrison, both from Canadian Broadcasting Corporation. ${ }^{20}$ All were committed to the common cause of rural adult education, and had particularly strong ideas about public education for citizenship. All three organizations were formed in the mid-1930s, and historians have argued that the remarkable success of the partnership was directly related to the fact that their "programs were relatively unformed." 21

\section{Adult Education and Rural Canada}

Increasingly locating farm problems and their solutions in policy decisions adopted by various levels of government, "people were pressing for solutions to their problems which farm and government organizations were either unable or unwilling to give." 22 Under the circumstances, as Alex Sim summarized, many people believed that "if agricultural conditions were to be improved, the farmers must take the responsibility for directing change. No one else would - or at least no else had up to then." ${ }^{23}$ As Morrison would later sum up for the 1954 Farm Radio Forum UNESCO report, "National Farm Radio Forum was promoted as an educational program, but there was no doubt in our minds that it was education for action to improve the economic and social lives of rural people." ${ }^{24}$

There was considerable overlap between the urgent need that many rural dwellers felt for a farm-centred movement for social and economic change and the goals of a rapidly emerging adult education movement in the country. ${ }^{25}$ For by the 1930 s, adult education, including rural adult education, was explicitly being seen as empowering the people to decide for themselves the goals of education. As H.D. Southam of McGill University's Adult Education Program argued,

Meaning must reside in the things for which people strive, the goals which they set for themselves, their wants, needs desires and wishes ... among other 
things, intelligence, power, self-expression, freedom, creativity, appreciation, enjoyment, fellowship ... they want to improve themselves; this is their realistic and primary aim. But they want also to change the social order so that vital personalities will be creating a new environment in which their aspirations may be properly expressed. ${ }^{26}$

The foundation of adult education and the much-hoped-for transformation of rural society tended to find common ground in the same solutions: self- help and co-operation. The former would ensure that rural people were taking responsibility for their own interests. Co-operation, many believed, would move them beyond the narrow individualism that many saw as the root cause of the decline of the family farm and 'rural values,' at the same time that it explained the rise of aliened urban communities and irresponsible 'big business' capitalism. Co-operation was, therefore, championed as " the key-stone of the democratic way of life and learning [for] the educational growth and welfare of any individual is bound up inextricably with the similar wellbeing of those with whom he comes in contact" ${ }^{27}$ while an ethic of self-help meant that people would "realize that they must assume responsibility and take action themselves towards a solution of the problems facing them." ${ }^{28}$

The National Farm Radio built explicitly upon a number of popular and distinctively rural grass-roots rural adult education programs that had already been developed in Canada, Sweden and Britain by the late 1930 s. $^{29}$ A number of Canadian organizations had already focused on rural and farming issues, including the Antigonish Movement, the St. Francis Xavier Movement, the New Canada Movement, The Folk Schools Community Life Conferences, Workingmen's Educational Association's 'Agricola' Study Groups, Farmers' University of the Air, and the United Farmers of Ontario Projects in Western Ontario. ${ }^{30}$ As Alex Sim concluded, by 1940 it seemed "that the chief aim of adult education in this young country has been to solve practical problems and to make life better in a material way." ${ }^{31}$ And the "increasing number of agricultural problems that required policy and action at the level of national government" had, by the mid-1930s, provided a rich source of the kind of "practical problems" that rural adult education could best explore. ${ }^{32}$

\section{The Radio}

The inauguration in 1936 of a national radio system, the Canadian Broadcasting Corporation (CBC) that could "span instantaneously the great Canadian spaces" provided the ideal means by which the urgent issues could be shared and mobilized via mass communication. ${ }^{33}$ Proponents of adult education and rural reform were well aware that social change would only be brought about if sufficient numbers of people could be brought together to discuss issues they considered important. The national programming of the CBC Farm Radio Forum provided a stage for the kind of "mass communication" needed to foster communication and, it was argued, social activism. ${ }^{34}$ A number of rural adult education organizations had, by the late 1930s, already made use of radio study or radio 'listening groups' to promote greater 
understanding of rural social issues in the hope of encouraging social (and socialist) activism. These included The Community Clinic, the Farm Problem Series, and the Inquiry into Cooperation. ${ }^{35}$ Listening groups had been popular in Britain and Canada from the 1920s onward, and had helped convince many of the considerable potential of the radio as educational medium. ${ }^{36}$ As one proponent of radio listening groups in the late 1930s put it, radio was a "gift" as an educational tool, one that had the power "to not only bring with it the conviction that we may be able to control ... the ether but also ourselves and our social problems, if only we go at them with sufficient seriousness and intelligence." He went further, suggesting that " $[\mathrm{w}]$ hen the function of radio is properly understood and rightly used it can be made a means of strengthening democracy and of unifying world society." 37

The potential of 'mass communication' technologies in furthering democratic citizenship through adult education had, therefore, already been identified when the Farm Radio Forum was proposed late in 1939 as a joint project by the three new organizations: the Federal Department of Agriculture, the Canadian Association for Adult Education, and the Canadian Broadcasting Corporation. But there were concerns about its potential for success. A number of adult educators, Alex Sim among them, were concerned that the passivity associated with listening would detract from the kinds of "informed action" that adult education in general, and the Farm Radio Forum in particular, were trying to nurture. The Farm Forum was, therefore, organized from the beginning so as the "passivity usually associated with listening was to be a preparation for action to follow:" 38

Action began with discussion. In fact it was often stated by the leaders that discussion is action; that ideas need not be restricted to the ivory tower, they can be put to work. A discussion group was to be an arena into which farm people come to sift the ideas and propounded in written word and broadcast. In the process they would give expression to their own ideas, impressions, prejudices, notion. Their own experience as adults, which could be counted on in many cases to be considerable, would also enter into the mainstream of the discussion... There was a firm belief in the shrewd judgment of the common man if proper conditions were provided for him to reach a decision. ${ }^{39}$

As the UNESCO report of 1954 summarized, "Whatever success Farm Forum has had is due, among other causes, to the fact that much more is offered than just a broadcast, and much more is expected of listeners than the formation of passive listening groups." 40

The Farm Radio Forum, therefore, built on and expanded the earlier experience of rural adult education organizations which had demonstrated the efficacy of dealing with the crisis in rural Canada through "the dual ideas of reaching many people at once, and of stimulating them to self-help through discussion groups." ${ }^{41}$ From the beginning, the Farm Radio Forum drew on a multi-media approaches and 'two way communication' to further its educational goals, summed up in its motto "Read, Listen, Discuss, Act." The Communications section of the 1954 UNESCO report outlines in considerable detail the ways in which information was exchanged 
amongst the Forums, the central offices, the broadcast audience, and the various organizations, political and economic, concerned with agricultural issues. From the National Office came the twenty weekly broadcasts each season, each including a five minute weekly summary of the provincial activities. Detailed diagrams in the Report outline how a variety of printed materials originated in the central offices of CAAE, CBC and CFA, were filtered through the policy and editorial board of the National Office of the Farm Radio Forum Office and out to the Provincial offices. These included the weekly Farm Forum Guide, the Pre-testing materials, an annual questionnaire and correspondence. Provincial offices forwarded these, along with a provincial newsletter and some supplementary literature, to the approximately 1,600 forums registered across the country, with the majority of these being in Ontario.

Moving in the other direction from the Forums to the Provincial Offices were queries, correspondence, contributions, and the all important 'Forum Findings' - the reports sent back to the Provincial Office by each Forum at the end of their evening's discussion. These individual Forum reports comprise a significant proportion of the materials held in the Farm Radio Forum fonds, and provide a remarkable overview of rural people's opinions, beliefs, hopes and fears. Provincial and National Offices also received the replies and the reports on pre-testing from selected Forums. Many of the local forums also sent reports on their activities to local newspapers and radio stations on a regular basis, distributing knowledge and information garnered at Forum meetings more broadly into the community. ${ }^{42}$ The Annual Questionnaire provided a wealth of feedback, and, like the Forum Findings, contains a remarkably rich source of information for anyone wanting to know about rural people in Canada at this time. Speaking of the CBC dramatizations, for example, E. Minitonas from Credit Union, Manitoba reported that in his opinion they were "[n]ot so snappy as Citizens' Forum and not so good arguments"; "Some were good. The average was good. A few stunk," came the response from the Arawana Forum, Butler, Manitoba, while the Argyle Forum in Elgin, Ontario, reported that "We, as a group, found them very satisfactory and would extend our sincere appreciation." The Farm Radio Forum broadcasts should "have more farmers as speakers," reported the Trent River West Forum, in Peterborough County; "We resent too many city people advising and criticizing us." ${ }^{43}$

Two elements were repeatedly identified as key to the success of the Farm Radio Forum programs, and both hinged on developing a high level of group discussion after the broadcasts: the availability of good quality educational materials to prompt a deeper level of discussion, and the sharing of the substance of these discussions with the rest of the country via a five minute provincial summary broadcast each week of the previous week's discussions. The Farm Forum Guide, created and compiled largely by the National Office secretary Ruth McKenzie, provided a variety of background materials relating to the issues being discussed, always from a variety of viewpoints. It also raised specific questions that were to guide the discussion after the broadcast. Arriving by mail on the Monday, it not only provided background information, but also often provided 'tips' for Forums on how to carry on a productive discussion. The National Farm Radio Forum National Office spent considerable time and effort deciding on and then refining the questions used to guide the discussion, using 
feedback from selected Forums to improve their quality in specially designed 'pretesting' sessions:

Anybody can ask a question but not everybody can ask a good question. Questions for group discussion are particularly hard to do well, as we have found out in Farm Forum ... For the past three years we have met some of these criticisms [question are 'ambiguous' or 'hard to understand' or 'silly' or '...' leading questions'...] in advance by trying out the questions on some 'guinea-pig' groups. Last year in Nova Scotia, Baddeck Bridge Forum help under direction of Miss Marjorie Nicholson. Mr. David Kirk of Regina conducted a group in Saskatchewan, and Miss Ruth McKenzie visited a different Ontario group for each series ... We hope to have three groups pre-test each set of questions again this year ... ${ }^{44}$

While this process was cumbersome and time consuming, Forum directors felt that such pre-testing was key to the success of Forum discussions that were at the heart of the Farm Radio Forum's success: "Taking into account the inexperience of many Farm Forum leaders, and the difficulties inherent in providing training in discussion methods, a series of provocative discussion questions" were key to stimulating the kinds of lively discussion that was required. ${ }^{45}$

After the broadcast and ensuing discussion, it was the responsibility of the Forum secretary to send a summary of the evening's discussion back to the Provincial office, where it would be reviewed for the issues it revealed, scanned for 'quotable' items to be included in the next week's provincial review, and then kept for statistical summary of provincial and national data that it provided. These also provided materials that were used to promote political action across the country. As Rodger Schwass explained in a $1993 \mathrm{CBC}$ radio interview,

[T] here was an elaborate feedback process. The thing also occurred in a period when there were very few sources of entertainment in the rural community, and you didn't have competition from television, for example. The farmers would listen to the broadcast, they'd study the study guides, they'd have their discussion, they'd make recommendations which could be sent up the Ministers of Agriculture or Education at the provincial level, and these were aggregated into a report that was taken to the federal Ministers. And, very often, there'd be direct feedback to those clubs the following week. And so, there was a continuing process of an elaboration of their ideas; it was an early form of "polling", really, and it gave the farmers a sense of being directly in touch with the centres of power in the country. ${ }^{46}$

\section{The Canadian Farm Radio Forum at work: Monday Nights in Rural Canada}

Having looked at the larger contexts of the Farm Radio Forum's purposes and origins, it is time to take a closer look at how it worked in practice. There were some changes 
over the course of the Farm Radio Forum's 25 years of broadcasting, but the overall structure remained basically the same. The initial meeting of a particular Forum might have been held in the local school and organized by one of the Field Men, typically a local farmer willing to work for this purpose for the Forum's provincial offices without pay. After the initial 'start up' meeting, however, most Forums would gather at the home of a neighbor, often changing the location on a rotating basis amongst the twelve-to-fifteen families that typically attended each Forum meeting.

Locating the meetings at neighbourhood homes increased the participation of women, a goal particularly sought by Alex Sim and other adult educators. ${ }^{47}$ As the UNESCO report noted, it was initially assumed that "the social and economic problems discussed at Forums were regarded as belonging to the male's sphere of interest and responsibility." ${ }^{8}$ From 1942 onward, however, it became increasingly common for women to attend with their husbands "in response to the continued insistence on the part of the national sponsors of the Farm Forum that it was a family affair, and to the recognition [sic] on the part of the members that interest would be increased by including women." A number of broadcasts dealt specifically with what were identified as 'women's issues', including: "Taking Stock of the Farm Home" (8 Feb. 1943); "What About Farm Home Improvements?" (11 Nov. 1946); "Is Farm Income Used Efficiently?" (2 Feb. 1948); "The Farmer Takes a Wife," (10 Nov.1947); "Boy Meets Girl" (1 Nov. 1948); "Farm Women in Public Life" (10 Nov. 1952); "More Attractive Homesteads" (9 March 1953); "Partners All" (9 Nov. 1953); "Citizens of Tomorrow" (7Dec 1953); and "Bringing up the Farm Family (17 Jan. 1955) and "The teacher in the Community" (8 Dec.1947). ${ }^{49}$ Evidence from the Farm Forum Findings, furthermore, demonstrates that women participated vocally to a wide range of broadcast topics relating to farming and farm life. As Monda Halpern has argued, while preliminary evidence from the Farm Forum Findings suggests that the Forum encouraged women's participation and willingly took on 'the woman question' in a variety of ways, they revealed both tensions between men and women, and a general recognition that women's role was different from but should not be subordinate to, that of men on the farm. Like the Women's Institute, it "sought to be current and progressive by contemporary standards." ${ }^{50}$ By 1954 , the UNESCO report concluded that in terms of Farm Forum attendance, "membership usually is evenly divided between the sexes." 51

Locating meetings at neighbours' houses also helped to nurture one of the most important elements of the Farm Radio Forum's success: re-building a sense of neighbourliness and community in rural areas in which year-round roads, the telephone, gasoline powered machinery were visibly breaking down the personal connections amongst farm families. ${ }^{52}$ And women's increasing role was identified as crucial to the success of this aspect of the Farm Forum's activities. ${ }^{53}$ When asked at the end of the first season of broadcasts "what can we accomplish through Farm Radio Forum," community building was high on the list: "We restore the old-time neighbourliness and learn how to work together through discussion," wrote V. Holliday, Secretary of one Ontario Forum. "We can acquire a more extensive knowledge on farm problems and the social side of our forums will eventually lead to better cooperative spirit 
among farmers," wrote Mrs. N. Thompson, Secretary of the King Ontario Forum. "It has been a means of the neighbours meeting together socially as well as being educational, thus creating a better community spirit", wrote "DW." ${ }^{54}$ Community building was a significant draw of the Farm Radio Forum nights, and was consistently listed as one of the most highly prized of its outcomes over its twenty-five year history. ${ }^{55}$

"When Monday night rolls around during the winter months," wrote one enthusiastic Farm Radio Forum advocate, "the rural neighbourhoods of Canada start to sparkle." ${ }^{6}$ Tens of thousands of men, women and children would leave their homes, get in their cars or hitch up their horses, and, bringing along the copies Farm Forum Guide that they had received by mail, go to a neighbour's house to meet up with the other (eight to fifteen) members of their local Farm Radio Forum. As Leonard Harmon's instructions suggested to Farm Forum participants for the 1 Dec.1941 broadcast and discussion entitled "Men and Machines," the evening was to begin as follows:

8.45: [Eastern Daylight Savings time] 20-30 people assemble in a farm home 8.55 Convener for the evening arranges people in positions to listen. Radio is tuned carefully for the broadcast

9:00 Meeting sings first verse of "Men of the Soil" with CBC quartet;

listening to the broadcast "Men and Machines" 57

As the Farm Forum Facts for that evening described it:

It is Monday night - Farm Forum Night. A group of farmers are gathered in a neighbour's kitchen. The radio is tuned in. Men of the Soil is heard. Every member listens attentively to the CBC broadcast. Their chairs are close to the radio. The room is well lighted. No doubt the fire is bright in the kitchen range. Everyone has a pencil and a slip of paper in order that no choice thought induced by the broadcast may be forgotten. Presently they will hear the Provincial News, possible the mention of their own group and their Forum Findings last week. Then they will gather in a circle to discuss Men and Machines. ${ }^{58}$

The song Men of the Soil was well known throughout the farm households of Canada in these years, and listeners, in the Forums or alone, were encouraged to sing along:

Men of the soil

Men of the soil,

Men of the soil

We have labored unending

We have fed the world upon the grain that we have grown

Now is the start of the new day ascending

Giants of the earth at last, we rise to claim our own

Justice throughout the land ... 
Then Farm Forum members were to listen attentively as the broadcast commenced. Described as "essentially serious broadcasts, designed to convey useful information about a topic of importance to the rural population of Canada," ${ }^{59}$ the program could take one or more of several different forms. The first broadcasts tended to be dominated by dramatizations (with the use of professional CBC actors) of neighbours living on the fictional Sunnybridge Farm, who would discuss the pros and cons of the topic under discussion later in the broadcast. Panel discussions, comprised of 'talking heads' addressing the issues relating to the topic at hand provided another, sometimes additional, form. Sometimes the program included speeches or interviews. As the Farm Forum Guide explained in 1952,

The speakers, who come from different parts of Canada, meet at a central point on the Thursday and Friday before the broadcast, and discuss the topic. The panel of speakers is chosen for their special knowledge of the subject or because they represent a particular point of view. In choosing the speakers, the Farm Department and the CBC consults farm organizations, adult education and business people from all over Canada. ${ }^{60}$

Before 1952, "the broadcasts were read by the speakers from a script that was prepared during their discussions," but these were widely "criticized for sounding stilted and artificial, and that is why the tape recording method was introduced." These broadcasts may have received mixed reviews from the listeners, but scripts continued to be "prepared by professional writers and are read by professional actors." ${ }^{11}$ The topics, the issues and the range of experts and 'ordinary people' invited to participate in the broadcasts were a source of considerable attention, concern and, according to historians, growing conflict over the years, as the aims of the three partner organizations diverged. ${ }^{62}$

For the first two or three years, a range of topics was represented throughout each broadcast season. A list of topics for broadcasts in the 1941-58 period is included as an Appendix to the online version of this article, and shows a wide range of programming, from topics relating to education and the farm family to farm credit, soil erosion, tariffs, farm management and a variety of health issues. After the first year or two, when no attempt was made to impose coherence to the topics presented each week, the Farm Radio Forum settled into a pattern where a single topic would be discussed over three weeks of broadcasts, with different aspects of the problem being aired each week. The fourth week of the month brought a 'review broadcast. Instead of a broadcast on a single topic, the review would include an overview of the month's broadcasts, and the extremely important 'round-up' of the reports sent by the Forum secretaries across the country. "The second portion of the same broadcast," as the UNESCO report summed up, "may consist of a series of speeches or interviews from Ottawa or Washington presenting the views of farm leaders on some topic of current importance to the rural population." ${ }^{63}$

Topics had to be chosen so that they "not only deal with a subject of interest to listeners, but the very wording of the topic must be so phrased as to encourage sharp exchange of views among the participants [in the broadcast] without favouring any 
point of view or suggesting a single solution." ${ }^{64}$ For at the heart of the Farm Radio Forum's mandate, and of its success, was the mission to engage rural people in discussion amongst themselves: "the true purpose of the broadcasts... Is...to bring out the various points of view and let the listeners reach their own conclusions." ${ }^{65}$ As Dr. Mary Needler pointed out in her review of the Farm Radio Forums in 1948, using radio to stimulate and support the kind of 'adult education' and social activism had tremendous potential, but as a new form of communication it presented unique challenges as well as possibilities. She worried that a particular partisan political group would take over discussions, inhibiting the thoughtful deliberation that was to be the foundation for Forum discussions - something that did not, however, materialize as a general problem. And she worried that the broadcasts themselves, although they typically represented a range of often contradictory opinions, at times did so by presenting some voices (in a Devil's Advocate spirit) just a little too strongly. Mostly, though, she worried that the kind of thoughtful and informed discussion that would provide a basis for grass-roots social activism embodied in the Farm Forum movement had few models for people to draw on:

An organization whose aim it is to enable the members to clarify their ideas and express their purposes cannot find its models for leadership in the average experience of business and government administration or even in teaching institutions such as church, school, Sunday school, social work, 'young people's organizations' etc. and that Farm Forum should therefore give more thought to the characteristics of the leadership it requires and to ways of developing these and shedding habits carried over from other experience. ${ }^{66}$

"What," she worried, " could have been done to restore the balance in favor of independent and critical thinking, after this heavy dose of 'being told'?"

Let us return to our Monday night broadcast, where the body of the broadcast had ended, and the monthly report from the provincial office was beginning. The provincial report would begin with an overview of the Forum Findings received, as it did on this broadcast of 15 Feb. 1943:

Thank you Harry Boyle and good evening farm people. Weather conditions again held report down to 234 meetings with 3,652 people in discussion. Concession 6 in Ramsay township of Lanark submitted a special request to call off the snowstorms and low temperature! Many secretaries reported that road were bad. Traveling by sleigh or by horseback or surmounting snow banks on foot, the Forums carried on. When some neighbourhoods were unable to meet, members listened at home and carried on discussion over the telephone. Bruce County came through with flying colors ... 44 reports from 701 people in one county. Other leading counties were Huron, Lanark, Grey and Dufferin. ${ }^{67}$

The Report would then move on to a more detailed overview of the topic of discussion, and the findings reported from the individual forums: 
Discussion last week was on the subject "Taking Stock of Farm Life" The first question had to do with the percentage of families in Forum communities having electric lights, running water, radio telephone and automobile. An average for all Ontario Radio Forum communities had been secured from the reports. The Forum communities having electric lights represent 24 per cent; running water seems surprisingly low, only 16 per cent, radio 78 per cent; telephone 76 per cent and automobile 89 per cent.

The second question dealt with enabling more farm families to have such facilities. While the average of the Ontario Farm communities is much higher than the general farm average for Canada, there certainly would be room for three times a many to have hydro and running water. Indeed we cannot consider our farms and farm homes to be well equipped until such is the case. Of course one of the big requirements to enable farm people to get these facilities was stated as the need for more favorable farm prices. The relations of the price the farmer pays for these things to the price the farmer receives for his product should be on a better basis. There can be little in a name. The following blunt statement came from Tranquility Forum in Brant: "There must be thorough organization by farmers so they can demand their rightful place in better farm income."

Credit unions were mentioned as a means of savings and credit to buy better facilities. A number objected to the inability of farmers to have hydro installed at present when electric motors, electric milkers, electric washers and lights for working in the house and barn could be such a help for the labor shortage We are trying to get official information on this point for mailing to the Forums....

The third question dealt with making community life more attractive. We should have more pride in our homes, more tolerance in our neighbourhoods, said a report from Prince Edward. Let's organize a moving picture service, said Malcolm, in Bruce. We need a community hall and a community park said Putnam in Middlesex. There's a vacant building in our community which could be turned into a recreation centre said Farm Forum near Paisley. The report did not say if the Forum intended to organize this or was only talking about it. Make the school a community centre said the Fifth Line of Sidney, in Hastings. Plant more trees and shrubs, said some. Have home improvement contests and circulating libraries said O'Herre. But Avonton, in Perth had a suggestion all their own ... a weeks holiday each year, with pay! ${ }^{68}$

It is difficult to know what criteria the Provincial office used to select comments for the provincial report back that comprised the Forum Findings. These certainly included slightly edgier comments, such as this one from 11th Line Beckwith, Lanark, Ontario, that were not included in Harmon's summary: "Steps should be taken to give the farmer equal share of the wealth for the labour he does in production. Electric lights would be more general if the rate were lower. If we had more returns 
from our produce we could install electricity and all modern conveniences;" or this one from Springville, Peterborough:

The farmers should be regarded as humans by "the powers that be" e.g. [people in ]war time housing can get and do get hydro and bath; [it] is supposed to be temporary houses while farmers now anxious for these cannot get them. These urban dwellers do not "need" these as do the hard-pressed rural people. Give us equality with urban people and we then [will be?] the preferred class ... One of these with water on tap has no car, radio, telephone or daily paper but has a very modern home in other respects [sic] It is not a religion that prohibits the conveniences either. None of the 25 have all five mentioned conveniences. ${ }^{69}$

Historians who have examined the broadcasts and the Forum Findings have, however, generally concluded that considerable care was taken to cover a range of opinions in both broadcasts and provincial reports, and that controversy was not generally avoided. ${ }^{70}$ The "report back in the last five minutes of the broadcast was of key importance, " noted historian Rodger Schwass. " [It] returned issues to the local to encourage new groups to form and to provide a summary of provincial forms and to make announcements." 71 The report back was at the heart of the "truly democratic group discussion-action method of Farm Forum."72

After the Forum members had listened to the final 'report back' from the Provincial office at the end of the half hour broadcast, it was time for the discussion of the new week's materials. As Leonard Harmon suggested in his notes, the broadcast might begin with a "prepared talk [...] delivered by the convener or by someone chosen by the convener a week in advance. Not to exceed 15 minutes. Subject: The Farm Labor Problem," ${ }^{73}$ It was probably more common, however, for discussion to start with a request to the group as to how many had read the materials supplied in the Farm Forum Guide. ${ }^{74}$ If most had not, then the first few minutes would be taken up with reviewing the Guide, perhaps reading it out loud and/or summarizing the range of opinions contained therein. Before discussion could commence in earnest, the format needed to be worked out. Harmon suggested the following:

9.45: Convener has decided the number of groups that can be formed. No group shall have more than 8 people. If attendance is only 9, the meeting should be divided into 2 groups. Suppose there are 26 people and the convener decides to have four groups. Convener decides where each group shall meet, and announces this decision. Convener counts the people 1-2-3-4-1-2-3-41-2- etc. Those who count one go into one group; those who count two go in group two, etc. Convener sees that in on minute each group chooses a leader for discussion and a secretary to take notes. ${ }^{75}$

The groups would then be given the task of discussing the issue of the evenings broadcast. In this case of the 1 Dec. 1941 broadcast, the following questions were discussed: 
1. Has the war caused a farm labour shortage in your community? Has the farm labor shortage affected production?

2. How many farmers in your neighborhood are using more machinery? What types?

3. In what way can farmers act to overcome the labor shortage? Should the government help? How?

A fourth question, "What percentage of farmer's sons and hired men have left your community in the past two year?" appeared in the planning stages, but was left off the final publication. ${ }^{76}$

As Mary Needler recognized, the success of the Farm Radio Forum was directly connected to the overall success of the Forum discussions. The UNESCO report noted that "the actual discussion may prove lively or dull, it may draw opinions from all members or it may be dominated by one or two talkative and opinionated persons." 77 Most participants agreed, however, that the experience of the discussion chair in drawing people out, and allowing for a range of opinions to be expressed and considered, was key to a successful Forum. Discussions would typically last from 30 to 45 minutes, though discussions could last as long as two or even three hours. The UNESCO report suggested that the level of the discussion had tended to improve with practice over the years, and that by 1954 it was unusual for Forums to disband because of "cleavages produced by raising "hot' political issues." 78 Of particular note in the detailed study completed of Halton County was the growing consensus about what constituted a good discussion leader "knowledge of the topic under discussion, enthusiasm, and ability to make everyone contribute to discussion." 79

As the UNESCO report pointed out, "discussion, like democracy itself, is based on the idea that no one has the key to truth, but that a tolerable working compromise may emerge when a group of people, adequately informed, have plenty of opportunity to talk things over." ${ }^{80}$ This Report, while generally very favourable about the success of Farm Radio Forum as an educational endeavour, was nevertheless skeptical that the Forums were capable of providing the kind of leadership and expertise needed to make such co-operative ventures in adult education actually work consistently in practice - particularly as the educational level attained by the majority of Forum participants was Grade $8 .^{81}$ While the success of these discussion groups is difficult to assess, historians looking at the evidence generally conclude, that against the odds, this particular manifestation of discussion-based adult education demonstrated remarkable success, particularly during the height of the Forum's popularity in the late 1940 s and early 1950 s. $^{82}$

Leonard Harmon's instructions went on to suggest that at 10:15, the "convener re-assembles people in larger meeting and conducts forum on findings of groups $s$ reported by group secretaries."

10:45 Radio Forum Business: Forum Secretary reads to the meeting the basis of registration as set forth on blue registration sheet and reads a second time the last paragraph dealing with Forum financing. Decision is made on provision of 
postage for the local Forum Secretary to send reports to the provincial office. Secretary takes up collection of at least 10 cents from each person present and sends the total amount to the Ontario Radio Forums Office.

11:00 Adjournment of discussion ${ }^{83}$

Before adjournment (which was typically well before $11 \mathrm{pm}$ ), Forum members were likely to engage in another important activity, one that many considered as vital to the purpose and goals of the Farm Radio Forum as were the educational broadcasts, the written study materials and the discussions: the 'social' or 'recreation period'. Many Forums spent an hour to an hour and a half socializing, most often by playing games, usually card games. The Farm Forum Facts published for the "Men and Machines" broadcast on 1 Dec. 1941, for example, suggested that a Recreation Director should be appointed a week in advance "so that he can have time to prepare for the recreation period." In case preparations had not been made, the Facts provided suggestions, with a detailed explanation of the game "Do This and Add Something" (a kind of Charades) and "Chinese Spelldown" (a backwards spelling bee [sic]). ${ }^{84}$ The social aspects of the Forums - games, singing, lunch, merely friendly chatting, was a big factor in attendance and contributed to the value people attached to the forums" reported N.M. Morrison; "one of the significant development observed in the functioning of the Farm Forums was the way in which the social and educational aspects of the work supplemented each other." 85

Social activities did not stop at the playing of games after the Farm Radio Forum broadcasts, however, but spilled over into the fourth element of the Farm Radio Forum Mandate: Act. The most widely acclaimed direct outcomes of the National Farm Radio Forum were the thousands of Action Projects emanating from local Forums to improve living and even working conditions in rural Canada during these years. These projects were, in the 1941-45 period largely limited to bringing in films and speakers, to providing additional information to rural participants in the Forums, and simply to organizing new Forums. Between the end of the war and the demise of the Forums in the early 1960s, however, the Farm Radio Forum nurtured significant projects across the country. Co-operative hospitalization schemes were popular, with Dufferin County Farm Forum leading the way by working with the Women's Institute and the County Federation of Agriculture to set up the first co-operative health plan on a county basis, with a further eight counties following suit in the $1946-7$ period. ${ }^{86}$ Others created projects to fight insect infestations, to improve school grounds and buildings, purchase new school equipment, provide hot lunches, or provide a school bus service. Others organized to provide snow clearance, or extend telephone service, and many worked to extend electrical service to neighbourhoods and individual homes. Some establish skating rinks, or recreational programs, or built community halls. Most included contributions to existing charitable organizations. And, as the UNESCO report described, there were a wide variety of co-operative enterprises created, including "Co-operative creameries, poultry pools, buying clubs for the purchase of supplies, egg-grading stations, credit unions, marketing schemes, locker plants, mutual fire insurance, and the purchase of machinery 
for common uses." ${ }^{87}$ By the mid-50s, in Ontario at least, "Farm Radio Foru m can be credited with a very significant contribution to the local action movement in in rural areas ... . On a very modest budget, it generated an incredible variety of projects and became a major social institution of the period." 88

\section{Conclusion}

The original, novel and indeed radical form and function of the Farm Radio Forum as a vehicle for rural education and social and political activism was a remarkable success, particularly in the 1945-1955 period, when the number of Farm Forums was in the thousands and the number of individuals actively involved numbered in the tens of thousands. Specific accomplishments of the Farm Forum included: "increased neighbourliness; a better understanding among farmers of the economic and social problems of the day; improved national understanding of rural issues; a more consistent, thoughtful voice for farmers; community development projects; the development of farm leadership." ${ }^{89}$ While the pro-cooperative and socialist bias claimed by some critics was never established,

[A]n investigation of the materials used during this (1941-54) period reveals a great deal of interest in co-operatives as a means for local action, and in the expansion of a broad array of social services. These services, requested in the 1941-51 period, included medical insurance, larger school districts, plowed winter highways - a Farm Credit Corporation and expanded community recreation facilities. The Forums were merely ahead of their time. ${ }^{90}$

Until the end of the 1940s, "there is little question that a part of the energy and initiative expressed by rural Canadians arose from the educational accomplishments of the Canadian Farm Radio Forum." ${ }^{11}$ The promise of the Farm Radio Forum to force policy changes that would allow for the preservation of rural communities failed, however, to materialize.

By the late 1950s, a variety of factors already visible in the 1920-1940 period, conclusively conspired against the goals of this innovative adult education/rural activist program. The goals of the three sponsoring institutions diversified as they matured, making it increasingly difficult for them to work together in a common cause. The organizational structure, which worked well enough in the short term with an audience that was united by a common cause of rural disempowerment slowly disintegrated as rural and farm populations plummeted in the post -1955 period. ${ }^{92}$ Alex Sim notes that funding for the project also fell dramatically in the years of declining enrolment. ${ }^{93}$ Historians have also noted the "the groups never became fully integrated into the Canadian national system of institutions or its power structure," ${ }^{44}$ which became increasingly corporatist, non-democratic and urban-focused in these years. By the 1950s, as Rodger Schwass goes on to suggest, "farm people recognized that they were no longer self-sufficient, and that changes had to be made in the scale and efficiency of farm business if incomes were to rise." Ready to adapt to change in 
some ways, they still could not accept "the need for farmers to leave the land in order that the incomes of those remaining might increase ... A general reaction was: 'The problem is not too many farmers, but lack of organization to control production." 95 National agricultural policies would simply not support this reading.

It is difficult to resist the interpretation that what the Farm Radio Forum gave to farm families for a brief period in the 1940s and early ' 50 s was the hope that Canada would be willing to sustain a political economy that would support local agriculture through small-scale petty commodity production on the family farm. As Rodger Schwass argues, after a period of prolonged depression, Farm Radio Forum gave the "family farmer the belief that he could deal with the problems which faced him and could succeed in making a decent living at the business of farming." ${ }^{6}$ Unfortunately, Schwass notes, "this impression was probably illusory and during the ' 50 s some of those farmers who remained in program grew once again embittered and apathetic concerning their prospects." ${ }^{77}$ In the decades following World War II, the Canadian government embraced a range of decisions that culminated in increasing land prices, farm mechanization, and more intensive mono-cropping, factors that eventually turned farming from a household enterprise designed to provide support for the Canadian family into a more competitive and lucrative business within the global economy. The Depression-era spectre of over-production motivated international players to seriously control and limit agricultural production at the level of national policy, while the high cost of new 'off-farm inputs' - fossil fossil fuel powered machinery, fertilizers and pesticides - that were boosting farm production also limited the number of existing farmers who could afford to make the shift to big business agriculture, even if they wanted to. As a result, by the post-World War II period, "one operator had to do the work of three men using older methods at the production costs of two thirds of the older methods." ${ }^{98}$ Food production was becoming more efficient, but increasing competition meant that small farms were being pushed out in favour of large operators. As one economist explained in 1950,

Forty acres and a mule is no longer an economic production unit... Sixteen acres of cropland per worker no longer represents a competitive work load ... $\$ 1,000$ per year is too little money; tractor power has reduced mule power... mechanization and consolidation might obviate the necessity of replacing many of the present antiquated farm structures. ${ }^{99}$

Within this context, "Farm consolidation, modernization and mechanization offer an economic solution to the problem of the land," but, as that economist poignantly asked, "what is the solution for the people?" 100 The short answer is that most were pushed out. The few who remained became large scale farmers, still working on family farms, but farms where commodification of food, fuel and labour had transformed life on the farm, as well as in the local community. ${ }^{101}$

Popular beliefs about the potential power of co-operative and peer-based learning, widespread recognition of the need to revitalize the countryside after years of Depression, and the democratic potential of the 'new media' were mobilized into the 
Farm Radio Forum by a variety of rural activists and sympathizers. Building on the earlier traditions in rural adult education, the format of the Forum was at the same time self-consciously innovative and experimental in the way that it tried to expand the (often short-lived) success of earlier movements and organizations. Nevertheless, the majority of farmers were forced off the land, or onto large farms in western and northern Canada, and the communities that had been built around them began to dissolve, and a way of life that had characterized the region for more than a century ended. For the time being, at least. The recent emphasis on local foods, brought about on the one hand by the awareness about what a global market for food transported by fossil fuels is doing to the global environment, and on the other by fears about food production standards in other countries, may bring these issues, so dear to the heart of Alex Sim, Leonard Harmon and E.A. Corbett, and others back again. Their work through the Farm Radio Forum in urging the importance of farmers, of local foods, and of local rural cultures to the health of a community and to a democratic nation, may yet hold some important lessons for our collective future.

\section{Notes}

1 R. Alex Sim, "Canada Farm Radio Forum," Fundamental Education, II (October 1950), 3-6. Cited in John Ohliger, "What Happened to the Canadian Farm Radio Forum?" Adult Education Journal, 18, 3 (1968): 176.

2 R. Alex Sim, "The National Farm Radio Forum: How it Worked," University of Guelph Archives, http://www.uoguelph.ca/-snowden/frf_how_it_worked.html, accessed 4 Jan. 2012.

3 Ohliger, "What Happened,"180.

4 E.A. Corbett, Director of CAAE, Ontario Farm Radio Forum Annual Meeting [1951?], quoted in LAC Typescript, n.d. [1952?], Farm Radio Fonds M28168, Vol. 10.

5 John Nicol, Albert A. Shea, G.J.P. Simmins, R.Alex Sim, eds. Canada's Farm Radio Forum (Paris: UNESCO, 1954), 70-71.

6 Proceedings, Winnipeg Farm Forum Conference, May 25-27, 1942, p. 4 cited in Rodger Schwass, "National Farm Radio: The History of an Educational Institution in Rural Canada," EdD, University of Toronto, 1972, 71.

7 Farm Radio International, Annual Report 2010-11, 3, available at http://farmradio. org/ See also African Farm Radio Research Initiative, Communicating With Radio: What Do We Know? Findings from Selected Rural Radio Effectiveness Evaluations (Farm Radio International, Ottawa, 2008); "George Atkins reflects back on 30 years of Farm Radio International" http://www.youtube.com/watch?v=y4FtIFD1EKA accessed 3 Jan. 2012.

8 Schwass, "National Farm Radio Forum," 154.

9 While Canada's population became officially more urban than rural from 1921 onwards, urban was a term defined exclusively by whether a municipality has been incorporated. Until 1951, it had nothing to do with the size of community. Even the proportion of the population living in urban Canada grew slowly, from 50 percent in 1921 to only 57 percent in 1951. Statistics Canada, Series A67-69. R.W. Sandwell, "Notes towards a History of Rural Canada, 1870-1940" in John R. Parkins, and Maureen G. Reed, eds., The Social Transformation of Rural Canada: New Insights into Community, Culture and Citizenship (Vancouver: UBC Press, forthcoming, 2012).

10 Adam Crerar, Abstract, "Ties that Bind: Farming, Agrarian Ideals and Life in Ontario, 1890-1930," PhD, University of Toronto, 1999. 
11 For the continued importance of rural society within twentieth century Canada, see for example Bradford James Rennie, The Rise of Agrarian Democracy: The United Farmers and Farm Women of Alberta, 1909-1921 (Toronto: University of Toronto Press, 2000). Nancy Christie and Michael Gauvreau, A Full-Orbed Christianity: The Protestant Churches and Social Welfare in Canada, 1900-1940, (Montreal and Kingston: McGillQueen's University Press, 1996), especially Chapter 5, "The Protestant Churches, the Social Survey, and Rural Planning;" Sandwell, "Notes towards a History of Rural Canada;" Mike Corbett, "A Protracted Struggle: Rural Resistance and Normalization in Canadian Educational History," Historical Studies in Education/Revue d'histoire de l'éducation, 13, 1 (2001): 19-48.; "Blossoms and Borders: Cultivating Apples and a Modern Countryside in the Pacific Northwest, 1890-2001," PhD, University of Victoria, 2008; Crerar, "Ties that Bind"; Monda Halpern, And on that Farm He Had a Wife: Ontario Farm Women and Feminism, 1900-1970 (Kingston and Montreal: McGill-Queen's University Press, 2001); R.W. Sandwell, "Rural Reconstruction: Towards a New Synthesis in Canadian History," Histoire Sociale/Social History, 27, 53 (May 1994):1-32 and "Missing Canadians: Reclaiming the A-Liberal Past" JeanFrançois Constant and Michel Ducharme, eds. Liberalism and Hegemony: Debating the Canadian Liberal (Toronto: University of Toronto Press, 2009), 246-273. and Hegemony: Debating the Canadian Liberal

12 For a discussion of rural reform movements in Canada, see for example Rennie, The Rise of Agrarian Democracy; Christie and Gauvreau, A Full-Orbed Christianity; Aubrey Wood, A History of Farm Movements in Canada: The Origins and Development of Agrarian Protest 1872-1924 (Toronto: University of Toronto Press, 1975); Kenneth Badgley, Ringing in the Love of the Common Good: The United Farmers of Ontario 191426 (Montreal and Kingston: McGill-Queen's University Press, 2000); David Quiring, CCF Colonialism in Northern Saskatchewan: Battling Parish Priests, Bootleggers and Fur Sharks (Vancouver: UBC Press, 2004).

13 Christie and Gauvreau, A Full-Orbed Christianity.

14 James Murton, Creating a Modern Countryside: Liberalism and Land Resettlement in British Columbia (Vancouver: UBC Press, 2007). The theme of 'rural abandonment' by an increasingly urban Canadian population has an important theme throughout the first half of the twentieth century and beyond, since the publication of John MacDougall's Rural Life in Canada: Its Trend and Tasks, first published 1913 (University of Toronto Press, 1973). For explorations of this important theme, see for example Christie and Gauvreau, A Full Orbed Christianity, Crerar, "Ties that Bind;" David C. Jones, Empire of Dust (University of Alberta Press, 1987). The theme has been picked up recently most consistently by rural sociologists and cultural geographers. See, for example, Roger Epp and Dave Whitson, Writing off the Rural West: Globalization, Governments and the Transformation of Rural Communities (Edmonton: University of Alberta Press, 2001) and Elizabeth Beaton, Ed. Connecting the Dots: Social and Scientific Perspectives on Agriculture and Rural Life in Atlantic Canada (Sydney: Cape Breton University Press, 2009).

15 For an overview of agricultural education in Canada in the early twentieth century, see Linda Ambrose, "'Better and Happier Men and Women': The Agricultural Instruction Act, 1913-1924" Historical Studies in Education/Revue d'histoire de l'éducation 16, (Fall 2004): 257-285. For an overview of Ontario Agricultural College's important role in adult rural education into the 1930s and beyond see Alexander M. Ross and Terry Crowley, (Toronto: Dundurn Press, 1999). College on the Hill: A New History of the Ontario Agricultural College, 1874-1999

16 John Nicol, Albert A. Shea, G.J.P. Simmins, R.Alex Sim, eds. Canada's Farm Radio Forum (Paris: UNESCO, 1954), 46. of Ontario farmers with government farm policies, see Crerar, "Ties that Bind," and on the prairies. 
17 Donald Cameron, "A National Policy for Rural Adult Education: An Address Given at the Annual Meeting of the CAAE University of Toronto. January 26 1940," NAC Avison File, 21, volume 4, quoted by Eleanor Beattie, "Public Education in the Mass Media: National Farm Radio Forum on CBC Radio," PhD, Concordia University, 1999, 53.

18 "History and General Information 1937-41" 2, National Farm Radio Fonds, MG28I68, Vol. 1A, LAC

19 Ibid, 3.

20 Ohliger, "What Happened," 177-8.

21 Ohliger, "What Happened," 180. Alex Sim had a slightly different take on the dynamism of the three new organizations that sponsored the Farm Radio Forum: "essentially it was a product of the inter war years when Canada had a brief respite from colonial domination having shaken off most of the ties to the British Empire we had not yet been absorbed into the hegemony of the United States of America. We were not only beginning to fashion our own foreign policy but also create new national organizations that were not copies of institutions developed elsewhere. I am thinking of the Canadian Clubs. The United Church of Canada, the Canadian Broadcasting Corporation, the Canadian Association for Adult Education among many others. The last two mentioned along with the Canadian Federation of Agriculture figure prominently in this story for they were joint sponsors..." R. Alex Sim, "The Farm Forum Story,” University of Guelph Archives http://www.uoguelph.ca/ - snowden/ frf_story.html accessed 4 Jan., 2012. Gerald Caplan documents that Gladstone Murray became a strong anti-socialist in the 1940s in The Cooperative Commonwealth Federation in Ontario, 1932-1945; a Study of Socialist and Anti-socialist Politics (Toronto:

University of Toronto Press, 1961).

22 Nicol et. al. eds. Canada's Farm Radio Forum, 40.

23 "Introduction" by R. Alex Sim, in Nicol, et al. eds., Canada's Farm Radio Forum, 22.

24 Nicol et. al. eds. Cited in Canada's Farm Radio Forum, 40.

25 For a history of rural adult education in Canada, see Gordon Selman, Citizenship and the Adult Education Movement in Canada (Vancouver: University of British Columbia Centre for Continuing Education, 1991). Ross and Crowley, College on the Hill; Terry Crowley, "The Origins of Continuing Education For Women: The Ontario Women's Institute," Canadian Woman Studies 7, 3, (Fall 1986); M.M. Coady, Masters of Their Own Destiny (New York: Harper and Row Publishers/ Antigonish Nova Scotia, NS Formac Publishing Col Ltd. 1933, 1967); A. Fitzpatrick, University in Overalls: A Plea for Part Time Study (Toronto: Hunter-Rose Co. 1920); E.A. Corbett, "A Short History of Adult Education," Food For Thought, The Canadian Association of Adult Education, August 1947.

26 H.D. Southam, Radio Listening Groups: A Course for Leaders (Department of Education, McGill University: published jointly by The Canadian Association for Adult Education; The Canadian Legion of the British Empire Service League; The Canadian Broadcasting Corporation p 10 [n.d. 1940?])

27 Southam, Radio Listening Groups, 11.

28 Nicol et. al., eds. Canada's Farm Radio Forum, 46.

29 For an overview of some of the issues that historians of rural non-agricultural adult education have more recently explored, see for example Pierre Walter, "Literacy, Imagined Nations, and Imperialism: Frontier College and the Construction of British Canada, 1899-1933," Adult Education Quarterly, vol. 54 no. 1 (Nov. 2003): 42-58, and Terry Wilde in this collection. For an overview of the National Farm Radio Forum as an example of citizenship education and mass media with specific reference to changing health delivery, see Eleanor Beattie, "Public Education in the Mass Media: National Farm Radio Forum on CBC Radio," PhD Concordia University 1999. Beattie provides a very useful literature review of the Farm Radio Forum in her introduction (12-31). 
30 Chapter 2: The Origins of National Farm Radio Forum," in Nicol, et al. eds., Canada's Farm Radio Forum, 40-43. For a history of these as forerunners of the National Farm Radio, see Rodger Schwass, "National Farm Radio: The History of an Educational Institution in Rural Canada," EdD, University of Toronto, 1972, especially Chapter 1 "Group Discussions in Canada in the 1930s"; and Beattie, "Public Education and the Mass Media." In LAC "History and General Information," file, Farm Radio Fonds, MG28I68, Vol. 1A, also provides a wealth of detail about the background in adult education out of which the Farm Radio Forum grew.

31 "R. Alex Sim, "Introduction," in Nicol, et al. eds., Canada's Farm Radio Forum, 18.

32 Ibid., 15.

33 Ibid., 15.

34 The role of the Farm Radio Forum as a vehicle of citizenship education across the country is explored in Paula Romanow, “'The Picture of Democracy We are Seeking:' CBC Radio Forums and the Search for Canadian Identity, 1930, 1950" Journal of Radio Studies, 12,1, (2005): 104-119.

35 "Chapter 2: The Origins of National Farm Radio Forum," in Nicol, et al. eds., Canada's Farm Radio Forum, 40-46.

36 For a discussion of CBC Radio Forums, Adult Education and the links to British roots, see Romanow, “'The Picture of Democracy We are Seeking:” and Ohliger, 178.

37 Southam, Radio Listening Groups, 13.

38 Nicol, et al. eds., Canada's Farm Radio Forum, 22

39 Ibid., 23

40 Ibid., 96. Emphasis in original.

41 Ibid., 41.

42 Part II, "The Lines of Communication," in Nicol, et al. eds., Canada's Farm Radio Forum, 95-154. See graphic representation on pages 97-99.

43 LAC, Comments re. Farm Broadcasts, 1944-52 [National]; Farm Radio Forum Fonds, MG28I68, Vol. 18 file D2.

44 "Pre-testing Questions," LAC, Farm Radio Forum Fonds, MG28I68, Vol. 18 file D3.

45 Nicol, et al., Canada's Farm Radio Forum, 140.

46 Excerpt from Interview with Rodger Schwass on CBC Morningside, June 18, 1993 , available at the University of Guelph Archives, http://www.uoguelph.ca/-snowden/ frf_interview.htm. Accessed 6 Jan. 2012.

47 Sim, "The Farm Forum Story, n.p

48 Nicol et al, Canada's Farm Radio Forum, 191.

49 For a full list of broadcasts to 1958 see LAC, "Classified List of Farm Forum Topics, 1941-58,” National Farm Radio Forum, MG28I68, Vol. 45 A5.

50 Halpern, And on That Farm, 122-3, and chapter 6 for a thoughtful discussion of the Farm Radio Forum, Women's Institutes and farm women in the 1950s and 60s. The detailed testimonials provided by women in the Farm Radio Forum Findings would provide an excellent source for examining Canadian rural women's attitudes across the country.

51 Nicol et al, Canada's Farm Radio Forum, 191.

52 "[V]isiting between neighbours appears to have declined in recent years. An important reason for this is that farmers can now pick and choose their friends with greater ease than formerly because virtually all farmers now have cars, the road system is good and they can visit back and forth with people over a far wider radius than they could have in the horse and buggy days. Informants have frequently commented upon and lamented, the fact that 'there isn't nearly as much neighbouring today as there was 10 or even six years ago." Nicol et al., Canada's Farm Radio Forum, 163-5. See also 19-20.

53 Nicol et al, Canada's Farm Radio Forum, 191.

54 LAC, "Farm Forum Findings 1941 [Ontario] November 10, 1941."Farm Radio Fonds, MG28I68, Vol. 45 C1. 
55 See for example Schwass, "National Farm Radio Forum," 150; The 1954 national survey conducted for the UNESCO report recorded that $70 \%$ of respondents responded that "neighourliness, sociability, community spirit" were the top reasons why they were interested in the Farm Radio Forum. Nicol, Canada's Farm Radio Forum, 83

56 Typescript, n.d. [1952?] LAC, Farm Radio Forum Fonds, MG18168, Vol. 10.

57 Farm Forum Findings, 1941 (Ontario), Farm Radio Forum Fonds, MG28I68 Vol. 45 C1, LAC.

58 Farm Forum Facts, Vol. 1, no. 3, December 1, 1941, "Men and Machines." LAC, Farm Radio Forum Fonds, MG28, Series T68, Vol. 106, Q4-16918.

59 Nicol et al., Canada's Farm Radio Forum, 103.

60 "How Broadcasts are Prepared" in "What About the Forum Broadcasts? "Farm Forum Guide, 14 Jan. 1952. LAC, File "Comments re. Farm Broadcasts, 1944-52 (National)," Farm Radio Forum Fonds, MG28I68, Vol. 18 file D2.

61 "How Broadcasts are Prepared."

62 Ohliger identifies the fact that "as the sponsoring institutions matured, their concerns diverged more and more" a problem that was manifested in the choice of topics for discussion, and their treatment. Ohliger, "What Happened," $180 \mathrm{ff}$. This point is also made by Schwass, who argues that "the diverse political objectives of the sponsors seem to have made unified action [regarding educational objectives] ...impossible." Schwass, "National Farm Radio Forum," 155.

63 Nicol et al., Canada's Farm Radio Forum, 104. Broadcasts were staggered by time zone across the country.

64 Ibid., 115.

65 "How Broadcasts are Prepared."

66 "Ontario Farm Forum Research Report: Confidential Submitted to Ontario Farm Radio Forum Executive by Mary C. Needler, PhD., March 1948.”LAC, Alberta Farm Radio Forum files MG28I68, Vol. 126.

67 "Taking Stock of Farm Life," Ontario Farm News Broadcast, 15 Feb. 1943; LAC, Scripts 1942-48 [Ontario]; Farm Radio Forum Fonds, M28 I68, Vol. 102 C6.

68 Radio Scripts, 1943, LAC, Farm Radio Forum Fonds, M28 I68 vol 102 C6.

69 Farm Forum Findings, 1941 [Ontario] 10 Nov. 1941, LAC, Farm Radio Fonds, MG28I68, Vol. 45 C1.

70 This is the general conclusion of Schwass, "National Farm Radio Forum," Ohliger, "What Happened," Beattie, "Public Education and the Mass Media," and Ron Faris, The Passionate Educators: Voluntary Associations and the Struggle for Control of Adult Educational Broadcasting in Canada, 1919-52 (Toronto: Peter Martin Associates, 1975).

71 Schwass, "National Farm Radio Forum," 68.

72 Ibid., 69.

73 Scripts, 1943, LAC, Farm Radio Forum Fonds, M28 I68, Vol. 102 C6.

74 For a detailed description of the Discussions in Halton County prepared for the UNESCO report, see Nicol, et al., Canada's Farm Radio Forum, 206-08.

75 Farm Forum Facts, Volume 1, no. 3, 1 Dec. 1941, "Men and Machines," LAC, Farm Radio Forum Fonds, MG28, Series T68, Vol. 106, Q4-16918.

76 Radio Forum Program Guide 1 Dec. 1941; Men and Machines, LAC, Farm Forum Findings 1941 [Ontario] MG28I68, Vol. 45 C1.

77 Nicol, et al., Canada's Farm Radio Forum, 144.

78 Nicol, et al., Canada's Farm Radio Forum, 206.

79 Ibid., 207.

80 Agricultural Co-operation: Guide for the Instructor (Booklet), Issued by the British Council. nd np., Cited in Nicol, et al., Canada's Farm Radio Forum, 148.

81 Nicol, et al., Canada's Farm Radio Forum, 149-51. 
82 This is Alex Sim's general conclusion, as summed up in the works cited here. It is also Mary Needler's tentative conclusion, notwithstanding her very prescient comments about the difficulties of maintaining appropriate leadership. Schwass, Ohliger and Beattie also concur about the remarkable success of the discussion groups at this time.

83 Scripts, 1943, LAC Farm Radio Forum Fonds, M28 I68, Vol. 102 C6.

84 Farm Forum Facts, Volume 1, no. 3, 1Dec 1941, "Men and Machines." LAC Farm Radio Forum Fonds, MG28, Series T68, Vol. 106, Q4-16918.

85 N.N. Morrison, "Report of the first season of the Farm Forums: Farmers Air their Problems"” Food for Thought, June 1941, 16 cited in Schwass, "National Farm Radio Forum," 67.

86 See Beattie, "Public Education in the Mass Media," for a discussion of the health initiatives taken on by the Farm Radio Forum groups.

87 These and many more are described in Nicol, et al., Canada's Farm Radio Forum, 84-89.

88 Schwass, "National Farm Radio Forum," 154.

89 Ibid.,150.

90 Ibid., 156.

91 Schwass, "National Farm Radio Forum," 151.

92 These are the conclusions forwarded reasonably by Ohliger, who suggests, further, that "the groups never became fully integrated into the Canadian national system of institutions or its power structure." Ohliger, "What Happened," 176.

93 R. Alex Sim, "The Farm Radio Story," http://www.uoguelph.ca/ -snowden/frf_story. html accessed 6 Jan. 2012.

94 Ohliger, "What Happened," 176.

95 Schwass, "National Farm Radio Forum," 65.

96 Schwass, "National Farm Radio Forum," 150.

97 Ibid., 150.

98 Leonard Hastings Schoff, A National Agricultural Policy for All the People of the United States prepared for the Columbia University Seminar on Rural Life (New York: Harper and Brothers, 1950), 29.

99 Ibid., 28-9.

100 Ibid., 29.

101 For a more detailed overview of what it had transformed rural life from, see Sandwell, "Notes toward a History of Rural Canada." 